\title{
Analisis Risiko e-Marketing untuk Industri Kecil dan Menengah
}

\author{
Ellysa Nursanti ${ }^{1 *}$, Sibut $^{2}$, Fuad Achmadi ${ }^{3}$ dan Timotius F.C.W. Sutrisno ${ }^{4}$ \\ 1,3 Program Studi Teknik Industri S2, Program Pascasarjana, Institut Teknologi Nasional ITN Malang 65145 \\ ${ }^{2}$ Program Studi Teknik Mesin, Fakultas Teknologi Industri, Institut Teknologi Nasional ITN Malang 65145 \\ ${ }^{4}$ Program Studi Manajemen, Fakultas Manajemen dan Bisnis, Universitas Ciputra, Surabaya 60219 \\ *E-mail: ellysa.nursanti@lecturer.itn.ac.id
}

\begin{abstract}
Abstrak
Kelompok pengrajin kerudung sulam bordir Bhakti Collection merupakan unit usaha mikro, termasuk dalam industri kecil dan menengah (IKM) yang dalam kegiatan penjualannya menggunakan metode penjualan tradisional, mengirimkan contoh produk ke industri usaha garment moslem, selanjutnya disepakati pemesanan dan barang akan diproduksi sesuai pesanan. Untuk meningkatkan penjualannya, unit usaha ini mencoba mengembangkannya melalui online marketing. Namun ternyata, unit usaha ini menemui kendala. Produk-produk unggulannya dijiplak oleh pihak yang tidak bertanggungjawab dan dibuat dalam jumlah masal dengan kualitas rendah dan dipasarkan. Kondisi ini sangat merugikan Bhakti Collection. Keadaan ini memotivasi tim penulis untuk membantu memberikan solusi melalui pendekatan metode analisis risiko e-Marketing dan memberikan usulan solusi pemasaran dan penjualan yang sesuai. Pertimbangan analisa kelayakan sederhana juga dilakukan untuk memilihkan alternatif solusi terbaik yang dapat memitigasi risiko yang ada sekaligus meningkatkan penjualan bagi unit usaha tersebut.
\end{abstract}

Kata Kunci: e-Marketing, Online Selling, Risiko, Usaha Mikro

\section{Pendahuluan}

E-marketing menggambarkan usaha-usaha perusahaan untuk menginformasikan, berkomunikasi, mempromosikan, dan memasarkan produk dan jasanya lewat internet. E-marketing memanfaatkan teknologi jaringan untuk mengkoordinasi penelitian pangsa pasar, membantu pengembangan produk, mengembangkan strategi dan cara untuk memikat pelanggan, menyediakan distribusi online, mempertahankan catatan pelanggan, menciptakan kepuasan pelanggan, dan mengumpulkan umpan balik pelanggan. E-marketing juga membantu dalam hal memajukan program pemasaran yang mendukung tujuan-tujuan perusahaan melaksanakan e-commerce [1]-[5].

Manajemen risiko menyoroti fakta bahwa kelangsungan hidup badan usaha bergantung sangat bergantung pada kemampuannya untuk mengantisipasi dan mempersiapkan perubahan, daripada menunggu perubahan dan kemudian bereaksi [6], [7]. Harus dipahami dengan jelas bahwa tujuan dari manajemen risiko bukan untuk mencegah atau melarang pengambilan risiko, tetapi untuk memastikan bahwa risiko secara sadar diambil dengan pengetahuan yang lengkap dan pemahaman yang jelas sehingga dapat diukur untuk membantu dalam mitigasinya [8]. Terlebih lagi dalam kasus UKM [7], [9]. Atribut penting dari bisnis yang sukses adalah efektivitas proses manajemen risikonya: semakin baik prosesnya, semakin pasti ada kemakmuran dan potensi keunggulan kompetitif jangka Panjang. Pentingnya usaha kecil telah ditekankan di seluruh dunia karena mereka mekanisme penciptaan lapangan kerja, inovasi dan pembangunan ekonomi yang tahan lama. Menurut hasil studi yang 
dilakukan oleh Lembaga Pengembangan Perbankan Indonesia dengan Bank Indonesia di tahun 2015, terdapat beberapa karakteristik yang khas dari usaha UMKM ini. Berikut adalah beberapa karakteristik khas tersebut, Kualitas produk atau jasa belum terstandar, desain produk yang terbatas, jenis produk atau jasa yang dihasilkan masih terbatas, kapasitas dan daftar harga produk yang terbatas, bahan baku kurang terstandar, hal ini dipengaruhi oleh sumber bahan baku yang berasal dari berbagai sumber yang berbeda-beda, maka hal ini tentu akan juga berpengaruh pada hasil produk yang dihasilkan. Keberlangsungan produk yang tidak terjamin dan kurang sempurna, hal ini dikarenakan umumnya produksi UMKM masih belum teratur sehingga akan berpengaruh pada produk yang dihasilkan juga masih terkesan apa adanya [10]-[12].

Berikut analisis situasi dan mengidentifikasi permasalahan di Bhakti Collection:

1. Analisis Situasi

Kelompok pengrajin kerudung sulam bordir Bhakti Collection merupakan unit usaha mikro yang berlokasi di jalan terusan bendungan wonogiri 21 Malang. Usaha ini memiliki beberapa workshop di Malang dan Pasuruan Jawa Timur. Dalam kegiatan penjualannya, unit usaha ini menggunakan metode penjualan tradisional, mengirimkan contoh produk ke industri usaha garment moslem nasional seperti Alisha, Shafira, Zoya, Preview, selanjutnya disepakati pemesanan dan barang akan diproduksi sesuai pesanan. Untuk meningkatkan penjualannya, unit usaha ini mencoba mengembangkannya melalui online marketing. Namun ternyata, unit usaha ini menemui kendala. Produk-produk unggulannya dijiplak oleh pihak yang tidak bertanggungjawab dan dibuat dalam jumlah masal dengan kualitas rendah dan dipasarkan. Kondisi ini sangat merugikan Bhakti Collection.
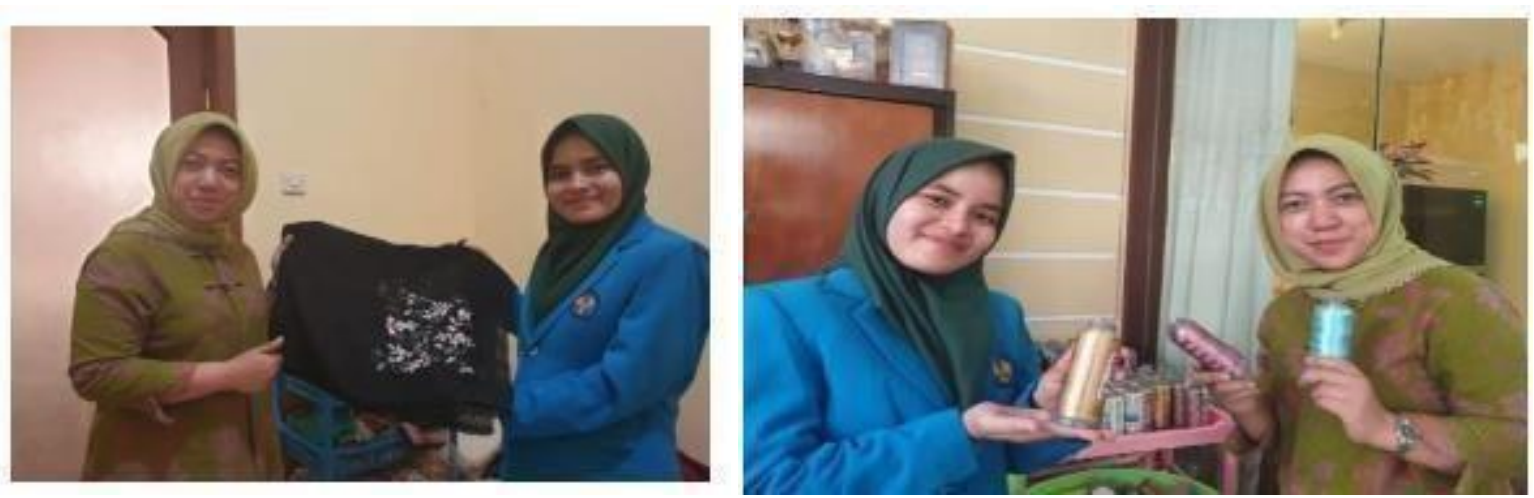

Gambar 1. Dokumentasi Kegiatan

2. Permasalahan Mitra

Permasalahan mitra adalah timbulnya risiko e-marketing akibat kegiatan penjualan online yang dilakukannya. Target semula dengan penjualan online, memperluas pasar potensial, memudahkan calon pembeli untuk memilih produk yang diinginkan, harapannya penjualan meningkat dan profit bertambah. Kenyataannya, contoh-contoh produk dijiplak oleh pihak yang tidak bertanggungjawab dan diproduksi dengan kualitas rendah serta dipasarkan. Produk jiplakan ini beredar di pasar lebih dulu sebelum produk asli dari mitra dipasarkan. Kondisi ini membuat penjualan jatuh karena di lapangan terdapat dua jenis barang yang dijual dengan motif sama namun kualitas dan harga berbeda, sehingga produk asli dari mitra tidak dapat terjual sesuai target. Pelanggan yang biasa membeli barang asli kualitas prima dari mitra, menjadi terganggu kepercayaannya. Hal ini sangat merugikan unit usaha mitra.

Meringkas persoalan yang ada, maka persoalan inti adalah bagaimana memproteksi produksi unit usaha mitra dari potensi risiko e-marketing. Persoalan ini terkait dengan dua bidang, yaitu bidang manajemen pengelolaan usaha dan bidang pemasaran penjualan. 


\section{Metode}

Metode pelaksanaan kegiatan pengabdian masyarakat ini menggunakan pendekatan Manajemen Risiko Teknik Industri. Mitra bergerak di bidang ekonomi produktif. Persoalan yang harus diselesaikan menyangkut dua bidang, yaitu pengelolaan manajemen dan manajemen pemasaran dan penjualan. Kedua bidang persoalan ini diatasi dengan pendekatan terintegrasi. Potensi risiko e-marketing diidentifikasi melalui observasi, wawancara, focus group discussion terhadap beberapa stakeholder terkait. Disini peran UMKM mitra saat diperlukan untuk dapat menggali data dan memetakan persoalan dengan baik. Identifikasi register risiko dilanjutkan dengan proses pengukuran dan analisis penyebab risiko tersebut. Dilanjutkan dengan mengembangkan alternatif solusi melalui scenario analysis dan melakukan studi kelayakan sederhana untuk mempertimbangkan alternatif yang ada dan mencari solusi yang dapat memiminimumkan risiko kerugian penjualan bagi UMKM Mitra. Hasil solusi dan metode langkah-langkah analisisnya dituliskan dalam buku panduan yang akan disisialisasikan oleh Tim Abdimas dan dapat digunakan sebagai pedoman arahan bagi UMKM mitra dalam melaksanakan manajemen risiko secara mandiri untuk potensi risiko lain yang mungkin terjadi.

\section{Hasil dan Pembahasan}

Persoalan utama kegiatan ini adalah bagaimana memproteksi produksi unit usaha mitra dari potensi risiko e-marketing. Persoalan ini terkait dengan dua bidang, yaitu bidang manajemen pengelolaan usaha dan bidang pemasaran penjualan.

Solusi permasalahan yang ditawarkan

1. Melalui pendaftaran hak cipta atas setiap model motif kerudung yang ada. Namun demikian, tetap harus dipertimbangkan sisi manfaat dan kerugiannya dari sisi ekonomis dan administratif karena jumlah model motifnya cukup banyak dan akan sangat memakan biaya yang juga relatif mahal.

2. Melakukan penjualan online terbatas dengan memilih model motif yang aman.

3. Melakukan pengiriman sampel ke konsumen bisnis industri karena penjualan berdasarkan trust ini juga memerlukan nilai perceived selling yang juga harus diperhatikan oleh mitra.

Metode pelaksanaan kegiatan pengabdian masyarakat ini menggunakan pendekatan Manajemen Risiko Teknik Industri.

1. Potensi risiko e-marketing diidentifikasi melalui observasi, wawancara, focus group discussion terhadap beberapa stakeholder terkait. Disini peran UMKM mitra saat diperlukan untuk dapat menggali data dan memetakan persoalan dengan baik.

2. Pengukuran dan analisis penyebab risiko tersebut.

3. Pengembangan alternatif solusi melalui scenario analysis dan melakukan studi kelayakan sederhana untuk mempertimbangkan alternatif yang

4. Mencari solusi yang dapat memiminimumkan risiko kerugian penjualan bagi UMKM Mitra.

Hasil solusi dan metode langkah-langkah analisisnya dituliskan dalam buku panduan yang akan disisialisasikan oleh Tim Abdimas dan dapat digunakan sebagai pedoman arahan bagi UMKM mitra dalam melaksanakan manajemen risiko secara mandiri untuk potensi risiko lain yang mungkin terjadi.

Solusi permasalahan yang ditawarkan adalah melalui pendaftaran hak cipta atas setiap model motif kerudung yang ada. Namun demikian, tetap harus dipertimbangkan sisi manfaat dan kerugiannya 
dari sisi ekonomis dan administratif karena jumlah model motifnya cukup banyak dan akan sangat memakan biaya yang juga relatif mahal. Solusi lain yang mungkin ditawarkan adalah melakukan penjualan online terbatas dengan memilih model motif yang aman. Alternatif lain adalah dengan tetap melakukan pengiriman sampel ke konsumen bisnis industri karena penjualan berdasarkan trust ini juga memerlukan nilai perceived selling yang juga harus diperhatikan oleh mitra. Beberapa solusi alternatif akan dikembangkan dan dibuat analisis kelayakan sederhana untuk dapat dipertimbangkan untung rugi setiap alternatifnya. Kegiatan ini akan melibatkan pendekatan manajemen risiko, strategi pemasaran penjualan serta analisis kelayakan untuk setiap scenario analysis yang dikembangkan. Beberapa penelitian yang telah dilakukan sebelumnya oleh ketua tim abdimas beserta para anggotanya pada tahun 2016, 2017, 2018, 2019 terlampir pada daftar pustaka akan menjadi pijakan bagi tim abdimas untuk memetakan masalah dan memberikan solusi terbaik bagi mitra.

\section{Kesimpulan}

Meskipun kesimpulan merupakan ulasan hasil utama atau kontribusi dari paper, tetapi jangan menduplikasi abstrak atau pendahuluan. Isi kesimpulan, anda bisa menguraikan pentingnya penelitian tersebut atau memberikan saran-saran yang bermanfaat untuk penelitian lanjutan. Berdasarkan seluruh rangkaian kegiatan Pengabdian Masyarakat yang dilakukan, dapat disimpulkan bahwa

1. Tidak selalu bahwa penjualan online itu menguntungkan pelaku usaha, khususnya untuk usaha industry kerajinan skala kecil menengah

2. Beberapa kerugian yang ditimbulkan akibat risiko e-marketing online selling adalah risiko model dijiplak, risiko kehilangan penjualan, risiko kehilangan kepercayaan pelanggan, risiko kehilangan nama baik

3. Walaupun demikian, tetap terdapat potensi keuntungan yang perlu dipertimbangkan yaitu penambahan potential customer, peningkatan transaksi penjualan

Mempertimbangkan kuntungan dan kerugian dari kediatan e-marketing online selling, maka penjualan online terbatas menjadi solusi yang tepat untuk mengatasi persoalan ini, dimana online selling tetap dilakukan, namun bukan untuk model/motif baru sehingga semua risiko yang mungkin terjadi, dapat diantisipasi dan keuntungan industry tetap dapat terproteksi.

Saran yang dapat diberikan kepada industri UMKM Bhakti Collection adalah

1. Memanfaatkan teknologi online marketing untuk memperluas potential market, melihat trend, mengetahui pola demand, spesifikasi dan transaksinya

2. Memperpendek masa jual offline sehingga dapat memperpendek siklus durasi model motif baru dipajang di etalase online sellingnya supaya tidak tertinggal trend updatenya.

3. Membuat pelatihan karyawan tentang hal ini.

\section{Daftar Referensi}

[1] T. Teofilus, T. F. C. W. Sutrisno, C. Hongdiyanto, and V. Wananda, "A study of indonesian online marketplace: Information processing theory paradigm," J. Distrib. Sci., vol. 18, no. 8, pp. 75-87, 2020, doi: 10.15722/jds.18.8.202008.75.

[2] S. Harianto and E. Nursanti, "Green Quality Improvement Using Six Sigma Method," Int. J. 
Innov. Sci. Res. Technol., vol. 5, no. 8, pp. 583-588, 2020, doi: 10.38124/ijisrt20aug266.

[3] F. Handoko et al., "Green Industrial System in Indonesia," MATEC Web Conf., vol. 164, pp. 17, 2018, doi: 10.1051/matecconf/201816401010.

[4] E. Nursanti, F. Handoko, and P. Vitasari, "Penerapan Manajemen Berbasis Database Dengan MS Access Untuk Meningkatkan Keunggulan Bersaing Pada Usaha Mikro," J. Teknol. Dan Manaj. Ind., vol. 3, no. 1, pp. 1-4, 2017, doi: 10.36040/jtmi.v3i1.170.

[5] C. G. Clarke, Online Marketing in a Small-Medium Enterprise (SME). In Saint Mary's University, 2013.

[6] M. C. Fatoni et al., "Analisis Risiko Key Performance Indicator ( KPI) Untuk Meningkatkan Pencapaian Target Nilai Kpi Tahunan Di PT Pamapersada Nusantara Distrik Baya. Program Studi Teknik Industri, Program Pascasarjana , Institut Teknologi Nasional Malang menggunakan Key Per," vol. 3, no. 2, pp. 144-147, 2020.

[7] E. Nursanti, Sibut, and Fuad Achmadi, "Implementasi Green Supply Chain Management Pada Kelompok Usaha Mikro," J. Teknol. Dan Manaj. Ind., vol. 5, no. 2, pp. 29-35, 2019, doi: 10.36040/jtmi.v5i2.279.

[8] E. Nursanti, Sibut, J. Hutabarat, and A. Septiawan, "Risk management in subsea pipelines construction project using Delphi method, FMECA, and continuous improvement," ARPN J. Eng. Appl. Sci., vol. 13, no. 11, pp. 3834-3838, 2018.

[9] E. Nursanti, Sibut, F. Achmadi, and D. P. Anugrahing Hapsari, "Penerapan Sistem Informasi Terintegrasi Untuk Meningkatkan Kenerja UKM Pengrajin Sulam,” J. Teknol. Dan Manaj. Ind., vol. 4, no. 2, pp. 18-23, 2018, doi: 10.36040/jtmi.v4i2.240.

[10] "Profil Bisnis Usaha Mikro, Kecil Dan Menengah (UMKM)," 2015.

[11] F. Handoko, E. Nursanti, D. Harmanto, and Sutriono, "The role of tacit and codified knowledge within technology transfer program on technology adaptation," ARPN J. Eng. Appl. Sci., vol. 11 , no. 8, pp. 5275-5282, 2016.

[12] E. Nursanti and F. Handoko, "Pemanfaatan Barcode Scanning Untuk Peningkatan Kualitas dan Inventory," pp. 26-28, 2016. 